\title{
Measurement of short-term changes in the fat content of the body: a comparison of three methods in patients receiving intravenous nutrition
}

\author{
BY D. J. ALMOND, ${ }^{*}$ R. F. G. J. KING, L. BURKINSHAW, $†$ C. B. OXBY \\ AND M. J. MCMAHON \\ University Departments of Surgery and Medical Physics, The General Infirmary, \\ Leeds LSI 3EX
}

(Received 20 September 1983 - Accepted 4 May 1984)

\begin{abstract}
1. Three methods of measuring changes in body fat were compared in seventeen patients undergoing a 2-week course of intravenous nutrition. Patients received all nutrition intraveneously at a steady rate of infusion, calculated to supply energy at a rate equal to 1.5 times the resting metabolic expenditure measured before feeding. Fat change was estimated from measurements of skinfold thickness, by isotopic methods (neutron-activation analysis and dilution of tritiated water) and by daily analysis of expired gases.

2. The mean (with $1 \mathrm{SEM}$ ) gain in fat over the 2 -week period was $1.14(0.30) \mathrm{kg}$ for skinfold measurement, 0.53 $(0.62) \mathrm{kg}$ for isotopic determination and $1.29(0.22) \mathrm{kg}$ for expired-gas analysis. There were no significant differences between the mean gains in fat measured by the three methods.

3. The results show that expired-gas analysis is the most sensitive technique, measuring change in fat content with an estimated precision of $0.26 \mathrm{~kg}$. The isotopic method is less sensitive, with a precision of $2.38 \mathrm{~kg}$, but provides a detailed description of body composition. In contrast to these highly-specialized techniques, both of which have limited application, the simple technique of measurement of skinfolds occupies an intermediate position of sensitivity, with a precision for measuring change in fat content of $0.85 \mathrm{~kg}$, and also has the potential to measure total body fat content.
\end{abstract}

The complications of malnutrition are usually associated with protein loss (Daly et al. 1972; Irwin \& Hunt, 1974; Bistrian et al. 1975). Not suprisingly therefore, considerable attention has been paid to changes in fat-free mass in patients receiving intraveneous nutrition (IVN). Patients who are fed intraveneously for short periods, however, make at the most small gains in lean body mass, most of the gain in weight being due to fat and water (Hill et al. 1979a; Macfie et al. 1981). Storage of fat must represent infused energy that is not immediately utilized (Wolfe et al. 1980) and may thus be of little benefit to the patient. Despite the importance of lean body mass, it may be more meaningful to examine the effects of parenteral nutrition, at least with respect to energy supply, on net change in body fat, the greater change in which may be more easily measured. In the present study we have compared different techniques for measuring short-term changes in body fat.

Body fat is usually determined by measuring the thickness of subcutaneous skinfolds using the method of Durnin \& Womersley (1974). This method was originally validated in healthy volunteers, a population different in many respects from patients in hospital. It is still unclear whether this technique is equally applicable to the critically ill, or appropriate for estimating short-term changes such as may occur during a course of intravenous feeding.

Since early this century (Zuntz \& Schumberg, 1901), it has been known that the nature of metabolic fuels can be determined from the ratio of the volumes of expired carbon dioxide and inspired oxygen (respiratory quotient; RQ) (Consolazio et al. 1963). If non-protein RQ is less than unity, net fat breakdown is occurring, but when RQ rises above $1 \cdot 0$, fat is being synthesized. Thus rates of fat synthesis and breakdown can be quantified from measurements

* Present address: Hope Hospital, Eccles, Greater Manchester.

$\dagger$ For reprints. 
Table 1. Details of patients included in the study

\begin{tabular}{|c|c|c|c|}
\hline $\begin{array}{c}\text { Age } \\
\text { (years) }\end{array}$ & Sex & Diagnosis & Energy source \\
\hline 78 & 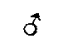 & Rectal neoplasm; post-operative vomiting & Glucose \\
\hline 57 & 8 & Crohn's disease; short bowel & Glucose, fat \\
\hline 76 & o & Vesico-colic fistula; diverticular disease & Glucose \\
\hline 61 & 3 & Total gastrectomy for neoplasm & Glucose, fat \\
\hline 66 & $q$ & Weight loss following ulcer surgery & Glucose \\
\hline 67 & $a$ & Small bowel fistula; laparotomy for adhesion & Glucose, fat \\
\hline 30 & q & Pancreatic pseudocyst & Glucose \\
\hline 44 & q & Enterocutaneous fistula & Glucose, fat \\
\hline 73 & $q$ & Oesophageal neoplasm; post-operative IVN & Glucose \\
\hline 21 & q & Ulcerative colitis & Glucose \\
\hline 53 & 우 & Vomiting following ulcer surgery & Glucose \\
\hline 40 & q & Pancreatic pseudocyst & Glucose, fat \\
\hline 58 & 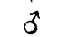 & Pancreatic pseudocyst & Glucose, fat \\
\hline 67 & 3 & Colonic neoplasm; preoperative IVN & Glucose \\
\hline 53 & 3 & Rectal neoplasm; anastomotic leak & Glucose \\
\hline 47 & $q$ & Duodenal fistula after bilary surgery & Glucose, fat \\
\hline 69 & 0 & Duodenal ulcer; preoperative IVN & Glucose \\
\hline
\end{tabular}

IVN, intravenous nutrition.

of the rate of consumption of $\mathrm{O}_{2}$ and the ratio, $\mathrm{CO}_{2}: \mathrm{O}_{2}$ in expired gas, provided that nitrogen balance and the energy source are known (R. F. G. J. King, D. J. Almond, C. B. Oxby and M. J. McMahon, unpublished results).

Body protein and minerals can be measured directly using neutron-activation analysis, and body water using dilution of tritiated water. Body fat can then be calculated by subtracting the sum of these components from body-weight (Hill et al. 1978). This method will be referred to as the 'isotopic' method.

Changes in body fat were measured by these three techniques in a group of patients undergoing a 2-week course of intravenous nutrition. The results suggest that gas analysis is the most sensitive and the isotopic method the least sensitive of these techniques for measuring change in body fat.

\section{PATIENTS AND METHODS}

Seventeen patients entered the study, all of whom received IVN for conventional clinical indications (Table 1); all nutrition was administered intravenously during the period of the study. Energy was provided either exclusively as glucose or as glucose and fat (Intralipid, Kabi-Vitrum Ltd, Uxbridge) in a ratio, $40 \mathrm{~kJ}$ glucose: $60 \mathrm{~kJ}$ fat. Non-protein energy was supplied at a level of 1.5 times the resting metabolic expenditure (RME), which was measured before the commencement of IVN. Synthetic L-amino acids (Fre-Amine II; The Boots Company plc, Nottingham) were supplied at an energy: $N$ value of $615 \mathrm{~J}$ $(150 \mathrm{kcals}) / \mathrm{g} \mathrm{N}$. The solutions were made up in 3-litre bags together with electrolytes, vitamins (Multibionta; Merck Ltd, Alton) and a solution containing trace elements, which was manufactured in the pharmacy of the General Infirmary at Leeds. The solutions were administered at a constant rate over each $24-\mathrm{h}$ period using an infusion pump.

Body size and composition were measured at the beginning and end of the 2-week period of study by the techniques described later. The ability of each technique to determine changes in the quantity measured was characterized by its precision, i.e. the standard deviation of repeated measurements of an individual of constant size and composition. 


\section{Body-weight}

The patients were weighed in light clothing using a beam balance (Avery $\mathrm{W}$ and $\mathrm{T}$ Ltd, Birmingham). The precision of the method was determined by weighing a single healthy man twelve times over a period of $14 \mathrm{~d}$. The measurements were made at arbitrary times during the day with the bladder empty and the subject dressed in conventional clothing without jacket or shoes. The observed precision was $0.21 \mathrm{~kg}(0.3 \%$ of the mean weight).

\section{Skinfold measurement}

Skinfold thickness was measured at the triceps, biceps, subscapular and suprailiac sites on the non-dominant side using Holtain calipers (Holtain Ltd, Crymych). Three measurements were made at each site and their mean values recorded. To determine the precision of the method, ten patients were measured on three separate occasions in $1 \mathrm{~d}$ by one observer. The precision of the sum of the four skinfold thicknesses was $0.73 \mathrm{~mm}$ ( $3 \%$ of the mean).

\section{In vivo neutron-activation analysis}

Each patient was irradiated with fast neutrons to a dose equivalent of $5 \mathrm{mSv}$ ( $500 \mathrm{mrem}$ ) in $40 \mathrm{~s}$ and then placed in a whole-body radiation counter for $30 \mathrm{~min}$ in order to measure the radioactivity induced in the body by the neutrons (Oxby et al. 1978). The spectrum of emitted gamma rays was analysed to determine total body $\mathrm{N}$, chlorine, potassium, phosphorus, calcium and sodium. The precision of measured total body $\mathrm{N}$, determined by measuring an anthropomorphic phantom forty-three times over a period of 14 months, was $50 \mathrm{~g} \mathrm{(3 \%}$ of the mean). The measured sum of the other five elements (the 'minerals')

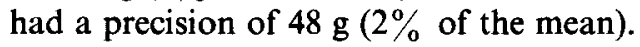

\section{Total body water}

The volume of redistribution of an intravenous bolus of $3.7 \mathrm{MBq}$ tritiated water given $4 \mathrm{~h}$ previously was calculated. When body water was measured at the termination of the study, a blood sample was taken before injection of the tracer in order to measure any residual activity remaining from the initial determination. The precision of this measurement was estimated to be $1.0 \mathrm{~kg}$, i.e. $2.5 \%$ of a typical body water content of 40 litres (Hill et al. $1979 \mathrm{a}$ ).

\section{Expired-gas analysis}

Analysis of expired gas was carried out daily for a period of $30 \mathrm{~min}$. Expired gas was collected by placing the patient beneath a square plastic canopy, each side of which measured $1.5 \mathrm{~m}$. The edges of the canopy rested loosely against the bedclothes. Outside air was drawn through the canopy and into a series of mixing chambers at a flow rate of 150 litres/min which ensured that all the patient's expired gas was collected. The apparatus used to control the flow of air through the canopy has been fully described by Kappagoda et al. (1974). The $\mathrm{O}_{2}$ and $\mathrm{CO}_{2}$ contents of the emergent gas were measured continuously with a paramagnetic $\mathrm{O}_{2}$ analyser (Taylor Servomex, Crowborough, Sussex) and an infra-red $\mathrm{CO}_{2}$ analyser (PK Morgan Ltd, Chatham).

After each measurement of a patient, the instruments were calibrated by measuring the changes in the flow rates of $\mathrm{O}_{2}$ and $\mathrm{CO}_{2}$ produced by introducing a certified reference gas mixture, at a known rate, into the air drawn through the canopy. The reference mixture (Special Gases, BOC Ltd, London) was similar in composition to the gases exhaled by the patients and its composition was verified by comparison with a gravimetric standard gas mixture (Gold Star; Special Gases, BOC Ltd, London). The flow of reference gas was controlled by a calibrated flow valve (Fisher-Porter, Workington). In a series of thirty measurements, the standard deviations of the changes in the flow rates, and hence of the 
simulated rates of consumption of $\mathrm{O}_{2}$ and production of $\mathrm{CO}_{2}$, were $23 \mathrm{ml} / \mathrm{min}$ of $\mathrm{O}_{2}(13 \%$ of the mean) and $17 \mathrm{ml} / \mathrm{min}$ of $\mathrm{CO}_{2}(9.2 \%$ of the mean $)$. These standard deviations included day-to-day variations in setting the flow of reference gas, and the total flow through the canopy, to constant nominal values.

\section{Change in body fat, calculated by three methods}

Calculation of body fat from skinfold measurements. Body fat was calculated from the sum of four skinfold measurements at the beginning and end of treatment by the method of Durnin \& Womersley (1974). Body density $(D)$ was first calculated using regression equations of the form:

$$
D=c-m \cdot \log (S 4),
$$

where $S 4$ is the sum of the four skinfold thicknesses $(\mathrm{mm})$ and the values of $c$ and $m$ are chosen to suit the age and sex of the patient (Durnin \& Womersley, 1974); $D$ is expressed as $\mathrm{g} / \mathrm{ml}$. The proportion of the body-weight which is fat, $f$, was then calculated using Siri's equation (Siri, 1956):

$$
f=(4 \cdot 95 / D-4 \cdot 5) \text {, }
$$

and the result multiplied by body-weight to give the total mass of fat. Change in fat content was then calculated as the difference between final and initial total body fat.

Calculation of fat change by isotopic determination of body composition. At the beginning and end of treatment, fat was calculated using the following formula (Hill et al. 1978):

$$
F=W-(6.25 \times T B N+T B W+M),
$$

where $F$ is body fat $(\mathrm{kg}) ; W$ is body-weight $(\mathrm{kg}) ; T B N$ is total body $\mathrm{N}(\mathrm{kg})$ measured by in vivo neutron-activation analysis; $T B W$ is total body water $(\mathrm{kg})$ by dilution of tritiated water; $M$ is total body minerals $(\mathrm{kg})$, i.e. the sum of the masses $(\mathrm{kg})$ of the elements $\mathrm{Ca}$, $\mathrm{K}, \mathrm{Na}, \mathrm{P}$ and $\mathrm{Cl}$ measured by in vivo neutron-activation analysis. Change in body fat was again calculated by subtracting initial from final body fat.

Calculation of fat change using analysis of expired gas. It is assumed that, in a steady state, the volumes of $\mathrm{O}_{2}$ consumed and $\mathrm{CO}_{2}$ produced are the sums of $\mathrm{O}_{2}$ utilized and $\mathrm{CO}_{2}$ produced by oxidation of glucose, fat and protein, and synthesis of fat; other reactions are assumed to produce and consume negligible amounts of $\mathrm{O}_{2}$ and $\mathrm{CO}_{2}$. It is also assumed that all $\mathrm{CO}_{2}$ produced is lost from the body by the normal processes of gaseous exchange. Then:

$$
\begin{aligned}
& \mathrm{O}_{2} \text { consumed }=\mathrm{O}_{2} \text { for net glucose oxidation }+\mathrm{O}_{2} \text { for fat oxidation } \\
& +\mathrm{O}_{2} \text { for fat synthesis }+\mathrm{O}_{2} \text { for net protein oxidation; } \\
& \begin{array}{r}
\mathrm{CO}_{2} \text { produced }=\mathrm{CO}_{2} \text { from net glucose oxidation }+\mathrm{CO}_{2} \text { from fat oxidation } \\
+\mathrm{CO}_{2} \text { from fat synthesis }+\mathrm{CO}_{2} \text { from net protein oxidation. }
\end{array}
\end{aligned}
$$

The volumes of $\mathrm{O}_{2}$ consumed and $\mathrm{CO}_{2}$ produced in the four metabolic processes were calculated by considering the molecular quantities of gases utilized and produced during the intermediate reactions of each process. The results are given in Table 2.

In the calculations, glucose was assumed to be oxidized completely, via glycolysis and the Krebs cycle, to produce only $\mathrm{CO}_{2}$ and water. Free fatty acids were assumed to be oxidized completely by the mitochondria; the fat being oxidized was assumed to consist of fatty acids of chain lengths representative of those found in normal adipose tissue. Complete oxidation of $70 \mathrm{~g}$ of normal protein was assumed to produce $2.4 \mathrm{~mol} \mathrm{CO}_{2}$ and consume $3.0 \mathrm{~mol} \mathrm{O}$.

The values for synthesis of fat were obtained by considering the synthesis of tripalmitin from glycerol and palmitic acid. In this process, acetyl $\mathrm{CoA}$ produced during normal glycolysis of glucose, NADPH derived from glucose-6-phosphate, and ATP, react in the 
Table 2. Volumes of carbon dioxide produced and oxygen consumed by each gram of substrate at standard temperature and pressure

\begin{tabular}{lccl}
\hline \hline & $\begin{array}{c}\mathrm{CO}_{2} \text { produced } \\
(\mathrm{ml})\end{array}$ & $\begin{array}{c}\mathrm{O}_{2} \text { consumed } \\
(\mathrm{ml})\end{array}$ & $\mathrm{RQ}$ \\
\hline Glucose oxidation & $829 \cdot 0$ & $829 \cdot 0$ & $1 \cdot 0$ \\
Fat synthesis & $1250 \cdot 6$ & $653 \cdot 1$ & $1 \cdot 91$ \\
Fat oxidation & $1334 \cdot 0$ & $1931 \cdot 0$ & $0 \cdot 69$ \\
Protein oxidation & $768 \cdot 0$ & $960 \cdot 0$ & $0 \cdot 80$ \\
\hline
\end{tabular}

$R Q$, respiratory quotient $\left(\mathrm{CO}_{2}\right.$ produced: $\mathrm{O}_{2}$ consumed $)$.

cytoplasmic pathways of the adipocyte to produce palmitic acid. Three molecules of palmitic acid and one of glycerol, derived from glucose, are then used to synthesize each molecule of tripalmitin. The values of $\mathrm{O}_{2}$ consumed and $\mathrm{CO}_{2}$ produced in the synthesis of tripalmitin were assumed to be valid for the synthesis of the triglycerides found in human adipose tissue.

If, in $1 \mathrm{~min}, \mathrm{~g} l \mathrm{~g}$ of glucose are oxidized, $s \mathrm{~g}$ of fat are synthesized, $b \mathrm{~g}$ of fat are oxidized and $p r g$ of protein are oxidized, then the rates of consumption of $\mathrm{O}_{2}$ and production of $\mathrm{CO}_{2}\left(\dot{V}_{\mathrm{O}_{2}}\right.$ and $\dot{V}_{\mathrm{CO}_{2}}$ respectively) are found by substitution from Table 2 into eqns (4) and (5) to give:

$$
\begin{aligned}
\dot{V}_{\mathrm{O}_{2}} & =829.0 \mathrm{gl}+653 \cdot 1 \mathrm{~s}+1931 \cdot 5 \mathrm{~b}+960 \cdot 0 \mathrm{pr} ; \\
\dot{V}_{\mathrm{CO}_{2}} & =829.0 \mathrm{gl}+1250 \cdot 6 \mathrm{~s}+1334.0 \mathrm{~b}+768 \cdot 0 \mathrm{pr} .
\end{aligned}
$$

Subtracting eqn (7) from eqn (6):

$$
\dot{V}_{\mathrm{O}_{2}}-\dot{V}_{\mathrm{CO}_{2}}=-597 \cdot 5 s+597 \cdot 5 b+192 \cdot 0 \mathrm{pr}
$$

and rearranging:

$$
\begin{gathered}
597 \cdot 5(s-b)=\dot{V}_{\mathrm{CO}_{2}}-\dot{V}_{\mathrm{O}_{2}}+192 \cdot 0 \mathrm{pr}, \\
s-b=\frac{\dot{V}_{\mathrm{CO}_{2}}-\dot{V}_{\mathrm{O}_{2}}+192 \cdot 0 \mathrm{pr}}{597 \cdot 5} .
\end{gathered}
$$

Now $s-b$ is equal to the net change in total body fat $(\Delta F ; \mathrm{g} / \mathrm{min})$. Therefore:

$$
\Delta F=\frac{\dot{\mathrm{VO}}_{2}-\dot{V}_{\mathrm{O}_{2}}+192 \cdot 0 \mathrm{pr}}{597 \cdot 5} .
$$

The overall rate of protein oxidation was calculated from the measured change in total body $\mathbf{N}$ and the total intake of amino acids. The rate of fat synthesis or breakdown was calculated during each of the daily $30 \mathrm{~min}$ periods of measurement. Fat change for the whole of the $14 \mathrm{~d}$ period was then calculated by integration assuming that a steady-state was maintained for each $24 \mathrm{~h}$ period. If fat emulsion had been administered as an energy source, the mass of infused triglyceride was added to the final fat balance.

\section{The sensitivities of the methods}

The estimated precision of each method of measuring fat content is given in Table 3 . The precision of the estimate from skinfold thickness was determined, as described previously, by repeated measurements of ten patients. The corresponding value for the isotopic method was calculated from the precisions of the measured values of $T B W, T B N$ and minerals. In both methods, the precision of measurement of body-weight made a negligible contribution to the precision of the measured fat content. 
Table 3. Estimated precisions of the three methods for measurement of change in fat*

\begin{tabular}{lccc}
\hline \hline & $\begin{array}{c}\text { Precision of } \\
\text { measurement of } \\
\text { fat content } \\
(\mathrm{kg})\end{array}$ & $\begin{array}{c}\text { Precision of } \\
\text { measurement of } \\
\text { fat change } \\
(\mathbf{k g})\end{array}$ & $\begin{array}{c}\text { Minimum significant } \\
\text { change in an } \\
\text { individual (kg) } \\
(95 \% \text { confidence limits) }\end{array}$ \\
\hline Skinfold measurement & 0.22 & 0.31 & 0.61 \\
Isotopic determination & 1.00 & 1.41 & 2.76 \\
Expired-gas analysis & - & 0.26 & 0.51 \\
\hline \hline
\end{tabular}

* For details of procedures, see p. 217.

For these two methods, the precision of measurement of a change in body fat, i.e. the standard deviation of a series of measurements of changes of equal magnitude, was found by multiplying the precision of measured fat content by $\sqrt{ } 2$. The resulting values are also given in Table 3, together with the corresponding value for the gas-analysis technique. In this case the precision of the measured change in fat content was calculated directly from the precisions of the measured consumption of $\mathrm{O}_{2}$, production of $\mathrm{CO}_{2}$ and change in body protein.

If the precision of measurement of a change is $p$, then a measured change in an individual whose fat content is actually constant has only a $5 \%$ chance of lying outside the range $\pm 1.96 p$. Thus a measured value outside this range can be regarded as strong evidence that a change has taken place. The quantity $1.96 p$ is referred to as the minimum significant change in body fat, and its value for each method is given in Table 3.

\section{Statistical methods}

Means, standard deviations, standard errors and correlation coefficients were calculated by standard methods. Differences between mean values of quantities measured by different techniques were tested for significance by Student's $t$ test for paired values. A probability of occurrence by chance $(P)$ of less than $5 \%$ was accepted as significant.

\section{Ethical considerations}

All patients consented to enter the study after the experimental procedures had been fully explained to them. The study was approved by the Research Ethics Committee of the General Infirmary at Leeds and by the Administration of Radioactive Substances Advisory Committee of the Department of Health and Social Security.

\section{RESULTS}

The mean values and standard deviations of body-weight and the components of body composition at the start of the study are given in Table 4. Values for body fat measured by both the skinfold and isotopic techniques are provided. The former method gave a value approximately $3 \mathrm{~kg}$ higher than the latter and the difference was statistically significant $(P<0.01)$. Table 4 also shows the mean values and standard deviations of the measured changes in body-weight and the components of the body over the period of the study. The only statistically significant changes were those in body fat measured by the skinfold and gas-analysis methods. The mean changes given by these two methods were in excellent agreement, and neither was significantly different from the mean change given by the isotopic method.

In Fig. 1, changes in body fat recorded for the individual patients by the three methods 
Table 4. Initial values and changes in the components of body composition of seventeen patients

\begin{tabular}{|c|c|c|c|c|c|c|c|c|}
\hline & & \multirow{2}{*}{$\begin{array}{c}\text { Body- } \\
\text { wt } \\
\text { (kg) }\end{array}$} & \multirow{2}{*}{$\begin{array}{l}\text { Body } \\
\text { water } \\
(\mathrm{kg})\end{array}$} & \multirow{2}{*}{$\begin{array}{l}\text { Body } \\
\text { protein } \\
(\mathrm{kg})\end{array}$} & \multirow{2}{*}{$\begin{array}{c}\text { Body } \\
\text { minerals } \\
(\mathbf{k g})\end{array}$} & \multicolumn{3}{|c|}{ Body fat $(\mathrm{kg})$ measured by:* } \\
\hline & & & & & & $\begin{array}{l}\text { Skinfold } \\
\text { method }\end{array}$ & $\begin{array}{l}\text { Isotopic } \\
\text { method }\end{array}$ & $\begin{array}{c}\text { Gas } \\
\text { analysis }\end{array}$ \\
\hline Initial value: & $\begin{array}{l}\text { Mean } \\
\text { SD }\end{array}$ & $\begin{array}{l}54.91 \\
11.68\end{array}$ & $\begin{array}{r}35.96 \\
6 \cdot 76\end{array}$ & $\begin{array}{l}8 \cdot 33 \\
1 \cdot 54\end{array}$ & $\begin{array}{l}1.54 \\
0.27\end{array}$ & $\begin{array}{c}12 \cdot 12 \\
8 \cdot 16\end{array}$ & $\begin{array}{l}9.07 \\
7.28\end{array}$ & - \\
\hline Change: & $\begin{array}{l}\text { Mean } \\
\text { SD }\end{array}$ & $\begin{array}{l}0.92 \\
2.93\end{array}$ & $\begin{array}{l}0.35 \\
3.58\end{array}$ & $\begin{array}{l}0.06 \\
0.89\end{array}$ & $\begin{array}{r}-0.02 \\
0.21\end{array}$ & $\begin{array}{l}1 \cdot 14 \\
1 \cdot 23\end{array}$ & $\begin{array}{l}0.53 \\
2.54\end{array}$ & $\begin{array}{l}1.29 \\
0.92\end{array}$ \\
\hline
\end{tabular}

* For details of procedures, see p. 217.

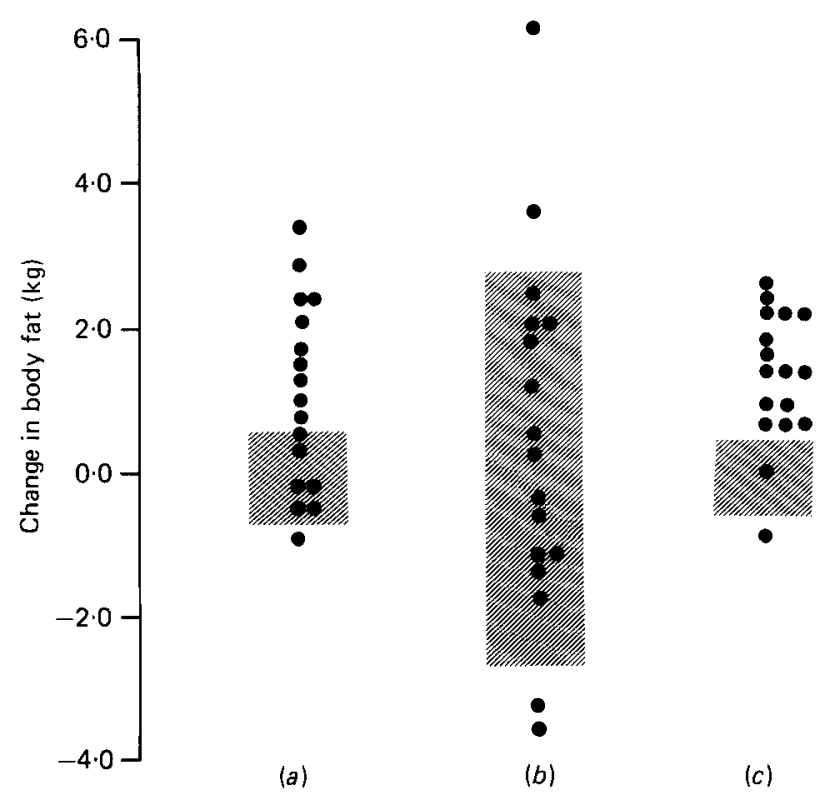

Fig. 1. Changes in body fat in individual patients estimated by three methods $(a)$ skinfold method, $(b)$ isotopic method, (c) analysis of expired gas (for details of methods, see p. 217). 图, Estimated minimum significant changes in an individual patient (for details, see p. 220).

are compared with the estimated minimum significant changes (Table 3). It was readily apparent that the isotopic technique had the poorest estimated sensitivity and gave the widest spread of values. The skinfold method occupied an intermediate position and the gas-analysis method had the highest estimated precision and the tightest grouping of values. Judging by their estimated sensitivities, the skinfold and gas-analysis methods were able to detect changes of the magnitude found in the study and indicated significant changes in eleven and sixteen patients respectively. The isotopic method, however, identified only four patients as having gained significant amounts of fat. There were no statistically significant correlations between the individual fat changes measured by the three methods. 


\section{DISCUSSION}

At the present time, there is no reference standard for the measurement of body fat. Perhaps the most widely accepted standard method is to estimate fat content from body density, measured by underwater weighing (Behnke et al. 1942). The procedure is, however, unsuitable for clinical use, and its accuracy has never been proven either in patients or in normal individuals. Thus techniques for measuring body fat and change in body fat can be assessed only by intercomparisons such as we report here.

When applied to our group of patients, the skinfold method gave a mean fat content $3 \mathrm{~kg}$ higher than that given by the isotopic method. This contrasts with the results of a comparison of the same two methods by Cohn et al. (1981). They found that, in normal subjects, the skinfold method gave lower mean values than the isotopic method, although it is difficult to compare their results directly with ours because they express fat content found by the skinfold method as a percentage of body-weight and that found by the isotopic method in $\mathrm{kg}$. They also measured patients with cancer, and their results suggest that the two methods give more concordant results for the patients than for the normal subjects.

These discrepant findings for different groups of subjects cannot be explained at present, but they may be related to the composition of the patients. It is tempting to assume that the isotopic method gives the more reliable mean value because it measures directly the mass of each primary component of the fat-free tissues, whereas the skinfold method has not been validated for subjects of abnormal composition.

Irrespective of the method used, patients in the present study showed a mean gain in fat, the mean value ranging from $0.53 \mathrm{~kg}$ for the isotopic method to $1.29 \mathrm{~kg}$ by expired-gas analysis. These values do not differ significantly from each other and are similar to results obtained from patients fed intravenously for 2 weeks in a previous study (Hill et al. 1979 a). The mean change measured by the isotopic method does not differ significantly from zero, but because the variance of the changes is large, it is impossible to determine whether this method genuinely gave a lower mean change than the other two methods.

There were no significant correlations between the three sets of values. This is hardly surprising, since the mean changes are comparable with the estimated precisions of the methods (Table 3). Thus any correlations that might exist will have been masked by the random errors of measurement.

The variance of the changes given by each method, $S^{2}$, is made up of a component $p^{2}$ representing the precision of the method for measuring changes and a component $\sigma^{2}$, which is common to all three methods and represents the true variability of fat changes among the patients. The variances $S^{2}, p^{2}$, and $\sigma^{2}$ are related by the equation:

$$
S^{2}=p^{2}+\sigma^{2} \text {. }
$$

Since $\sigma^{2}$ is theoretically identical for each method, the rank order of the observed variances should be the same as the rank order of the estimated precisions given in Table 3; the experimental values support this hypothesis. The values can, however, be analysed further in order to test the consistency of the estimated precisions.

Gas analysis had the smallest precision for measuring a change in body fat $(0.26 \mathrm{~kg})$ and gave values with the smallest standard deviation $(0.92 \mathrm{~kg})$. Thus, to satisfy eqn $(12)$, the value of $\sigma$ must be $0.88 \mathrm{~kg}$. If we assume that this value represents the true variation between patients, we can substitute it, together with the observed variances of the other two methods, into eqn (12). We then arrive at new values $(0.85 \mathrm{~kg}$ for skinfold measurement and $2.38 \mathrm{~kg}$ for the isotopic method) for the estimated precision of measured change $(p)$. Although with this small study of seventeen patients there will be considerable uncertainty in these new estimates of precision, they are markedly greater than the values given in Table 3. 
Alternative estimates can be found by substituting into eqn (12) the values of $S$ and $p$ obtained by skinfold measurement or the isotopic method, and each result used to estimate the precision of the other two methods. In each case the calculation gave a negative value of $p^{2}$ for the gas analysis method. This supports our conclusion that the values in Table 3 underestimate the precisions of the skinfold measurement and the isotopic method.

The new value for the precision of a change in body fat measured by the skinfold method $(0.85 \mathrm{~kg})$ is approximately equivalent to a precision of measurement of the sum of four skinfold thicknesses of $2.0 \mathrm{~mm}$. This is comparable with the range of values $(2.0-4.3 \mathrm{~mm})$ found by Womersley \& Durnin (1973) when they measured a number of medical students repeatedly, but greater than the value of $0.73 \mathrm{~mm}$ found by repeated measurements of ten patients, as described on p. 217, which led to the estimated precision given in Table 3 . The most likely explanation for this difference is that our measurements were made by a single operator in $1 \mathrm{~d}$. In these circumstances the operator probably achieved maximum consistency and the subjects' body-weights did not change. The patients in the study were measured on two occasions separated by $14 \mathrm{~d}$, during which time there were considerable changes in body composition. Thus the relationship between skinfold measurement and body composition may have changed over the interval.

The revised estimate of the precision of measurement of change in fat by the isotopic method $(2.38 \mathrm{~kg})$ corresponds to a precision of measuring fat content of $1.68 \mathrm{~kg}$. The discrepancy between this value and the value given in Table 3 would be explained if (a) the precision for measuring total body water was $1.7 \mathrm{~kg}$ rather than $1.0 \mathrm{~kg}$, (b) the precision for $T B N$ was $216 \mathrm{~g}$ rather than $50 \mathrm{~g}$, (c) the precision for minerals was $1.3 \mathrm{~kg}$ rather than $48 \mathrm{~g}$, (d) the precision for body-weight was $1.3 \mathrm{~kg}$ rather than being negligible or (e) if two or more of the precisions were increased by smaller amounts. We have shown that the body-weight of a volunteer could be measured with high precision even when normal day-to-day variations were included in the measurements. There is no reason to suppose that the precision for body-weight was different in the present study. It is extremely unlikely that the precision for minerals was as high as $1.3 \mathrm{~kg}$ (twenty-seven times the measured value). It is also unlikely that the precision of $T B N$ was four times the expected value; duplicate measurements of $T B N$ in patients on successive days have been found to be as reproducible as measurements of phantoms (Oxby et al. 1978). We conclude, therefore, that the most likely source of imprecision was the measurement of total body water.

The discrepancies between the estimates of precision could also be explained if the gas-exchange method underestimated the variability of the changes in fat. However, even if this accounted for the apparently higher value for the precision of the skinfold method, it would not account for all of the unexplained variability of the isotopic method.

Expired-gas analysis was performed for only $30 \mathrm{~min}$ each day and it was assumed that the rates of $\mathrm{O}_{2}$ consumption and $\mathrm{CO}_{2}$ production during this period were representative of the whole day. This was justified on the grounds that the patients were inactive physically, and the nutrients were given at a constant rate over $24 \mathrm{~h}$.

Expired-gas analysis directly measures the rate of change of body fat. Using this method, it is possible to compare different energy sources, using each patient as his own control. The question of what is the most suitable source of energy for use in intravenous nutrition is as yet unanswered, but expired-gas analysis may be a valuable tool for comparing different intravenous regimens. Using skinfold measurements, 1.8 times as many patients would need to be studied on the basis of our results to obtain as small a standard error as with analysis of expired gas. Thus whilst skinfold measurement is a useful method for groups of patients it is probably somewhat less sensitive for individuals or small numbers of patients than analysis of expired gas.

Compared with the other two techniques, the isotopic method is an imprecise way of determining short-term changes in body fat. However, it shares with the measurement of 
skinfolds the ability to determine the proportionate fat content of the body. In addition, it gives the masses of the major components of the fat-free tissues (water, protein and minerals) and the amounts by which they change. Such information is potentially of great interest. For example, in the present study, the results suggest that almost $30 \%$ of the weight gain may have been water; the observation cannot be confirmed statistically in this case, but the method has shown significant gains of water in other groups of patients fed intravenously (Hill et al. 1979a). Expired-gas analysis gives no information about initial and final body composition and is only relevant to measurement of changes in fat.

Garrow et al. (1979) determined the amounts of fat lost by nineteen obese women by measuring energy balance, $\mathrm{N}$ balance, body density, body water and body $\mathrm{K}$. They found that energy balance gave the smallest standard deviation and body $\mathrm{K}$ the largest, with the other methods ranked between them in the order given previously. They analysed their results as we have ours, except that they made no correction for the estimated precision of the energy-balance method ( $p$ in eqn (12)). They found precisions for the measurement of a change ranging from $1 \mathrm{~kg}$ fat for the $\mathrm{N}$ balance method to $3.47 \mathrm{~kg}$ fat for the body $\mathrm{K}$ method, results generally similar to those we find for the skinfold and isotopic methods $(0.85 \mathrm{~kg}$ and $2.38 \mathrm{~kg}$ respectively). Our isotopic method was related to the Garrow et al. (1979) methods based on measurements of $\mathrm{N}$ balance, body water and body $\mathrm{K}$ but, unlike them, makes no previous assumptions about the proportions of water, protein and minerals in the tissues gained or lost. This seems particularly important when measuring surgical patients fed intravenously, since there is evidence to show that the amounts of water, protein and $\mathrm{K}$ gained or lost are not necessarily in the proportions found in normal lean tissue (Hill et al. $1979 a, b)$.

In summary, we have compared three independent methods: skinfold measurement, in vivo neutron-activation analysis and expired-gas analysis for the measurement of change in fat in patients receiving a 2-week course of intraveneous feeding. All three methods gave very similar mean results showing their consistency even though their accuracy could not be confirmed in the absence of an absolute standard of reference.

Expired-gas analysis was the most precise of the methods (estimated precision $0.26 \mathrm{~kg}$ ) and gave the smallest standard error. However, it can only be performed under carefullyspecified experimental conditions, when exact nutritional balance can be measured. The isotopic method had the poorest precision for measuring change in body fat $(2.38 \mathrm{~kg})$. Complex equipment is required but the technique does also measure total body composition. Measurement of change in body fat by measuring skinfold thickness occupied an intermediate position with respect to sensitivity (precision $0.85 \mathrm{~kg}$ ). This technique is quick, non-invasive and possesses the additional advantage that total body fat content can also be calculated.

The authors are grateful for the assistance given by Mr J. Holmfield in performing expired-gas analysis, Miss D. W. Krupowicz in performing in vivo neutron-activation analysis, Dr A. H. Smith with the measurement of ${ }^{3} \mathrm{H}_{2} \mathrm{O}$ and $\mathrm{Mr}$ A. Laughland with the calculations. D.J.A. was supported by a grant from The Boots Co. plc. Development and use of in vivo neutron-activation analysis were supported by a programme grant from the Medical Research Council. Help with the provision of equipment and materials was provided by Kabi Vitrum Ltd.

\section{REFERENCES}

Behnke, A. R., Feen, B. G. \& Welham, W. C. (1942). Journal of the American Medical Association 118, $495-500$. Bistrian, B. R., Blackburn, G. L., Scrimshaw, N. S. \& Flatt, J. P. (1975). American Journal of Clinical Nutrition 28, 1148-1155.

Cohn, S. H., Ellis, K. J., Vartsky, D., Sawitsky, A., Gartenhaus, W., Yasumura, S. \& Vaswani, A. N. (1981). American Journal of Clinical Nutrition 34, 2839-2847. 
Consolazio, F. W., Johnson, R. E. \& Pecora, L. J. (1963). Physiological Measurements of Metabolic Functions in Man. New York; McGraw Hill.

Daly, J. M., Vars, H. M. \& Dudrick, S. J. (1972). Surgery, Gynaecology and Obstetrics 134, 15-21.

Durnin, J. V. G. A. \& Womersley, J. (1974). British Journal of Nutrition 32, 77-97.

Garrow, J. S., Stalley, S., Diethelm, R., Pittet, Ph., Hesp, R. \& Halliday, D. (1979). British Journal of Nutrition 42, $173-183$.

Hill, G. L., Bradley, J. A., Smith, R. C., Smith, A. H., McCarthy, I. D., Oxby, C. B., Burkinshaw, L. \& Morgan, D. B. (1979a). Journal of Parenteral and Enteral Nutrition 3, 215-218.

Hill, G. L., King, R. F. G. J., Smith, R. C., Smith, A. H., Oxby, C. B., Sharafi, A. \& Burkinshaw, L. (1979b). British Journal of Surgery 66, $868-872$.

Hill, G. L., McCarthy, I. D., Collins, J. P. \& Smith, A. H. (1978). British Journal of Surgery 65, 732-735.

Irwin, T. T. \& Hunt, T. K. (1974). Annals of Surgery 180, 765-772.

Kappagoda, C. T., Stoker, J. B. \& Linden, R. J. (1974). Journal of Applied Physiology 37, 604-607.

Macfie, J., Smith, R. C. \& Hill, G. L. (1981). Gastroenterology 80, 103-107.

Oxby, C. B., Appleby, D. B., Brooks, K., Burkinshaw, L., Krupowicz, D. W., McCarthy, I. D., Oldroyd, B., Ellis, R. E., Collins, J. P. \& Hill, G. L. (1978). International Journal of Applied Radiation and Isotopes 29, $205-211$.

Siri, W. E. (1956). Body Composition from Fluid Spaces and Density: Analysis of Methods. University of California Radiation Laboratory Report UCRL no. 3349.

Wolfe, R. R., O'Donnell, T. F., Stone, M. D., Richmand, D. A. \& Burke, J. F. (1980). Metabolism 29, $892-900$. Womersley, J. \& Durnin, J. V. G. A. (1973). Human Biology 45, 281-292.

Zuntz, N. \& Schumberg, N. A. E. F. (1901). Studien zu einer Physiologie des Marsches. Berlin: A. Hirshwald. 